\title{
Strategi Pengembangan Sistem Informasi Berbasis E-KTP di Kantor Kelurahan Galur (Studi Kasus Kelurahan Galur Kota Jakarta Pusat)
}

\author{
Endang Supriyadi ${ }^{1}$, Maya Sofiana ${ }^{2}$
}

\begin{abstract}
Information System is a system within an organization that manages daily transaction processing needs that support operations and also in strategic activities within an organization by providing the necessary reports. Along with the rapid development of information and communication technology, it is now possible for people to be able to access any information they need in their daily lives, as if there were no limits. One of the programs that the Ministry of Home Affairs of the Republic of Indonesia is starting to implement now is to utilize information technology in providing services to the community in the form of implementing the Electronic Identity Card program or also known as e-KTP. Electronic ID card is a population document that contains a security / control system both in terms of administration or information technology in the database to the national occupation. To obtain completeness of data and information in accordance with the focus of the study, the data collection technique used in this study used a questionnaire. The author concludes that by using the IFAS and EFAS matrix patterns that have been carried out, it can be seen the condition of Galur Village in developing an E-KTP-based information system, namely with technological advances and the implementation of employee empowerment in the field of technology, it can further improve the vision and mission that supports quality of village services.
\end{abstract}

Intisari - Sistem Informasi adalah suatu sistem yang berada dalam suatu organisasi yang mengelola kebutuhan pengolahan transaksi harian yang mendukung operasi dan juga dalam kegiatan strategi dalam suatu organisasi dengan menyediakan laporan-laporan yang diperlukan. Seiring dengan perkembangan teknologi informasi dan komunikasi yang semakin pesat saat ini sangatlah memungkinkan masyarakat untuk bisa mengakses informasi apa saja yang mereka butuhkan dalam kehidupan sehari-hari, seolah-olah tidak ada batasannya. Salah satu program yang mulai diterapkan sekarang ini oleh Kementrian Dalam Negeri Republik Indonesia adalah dengan memanfaatkan teknologi informasi dalam melakukan pelayanan kepada masyarakat adalah berupa penerapan program Kartu Tanda Penduduk Elektronik atau disebut juga e-KTP. KTP Elektronik adalah dokumen kependudukan yang memuat sistem keamanan pengendalian baik dari sisi administrasi ataupun teknologi informasi pada data base ke pendudukan nasional. Untuk mendapatkan kelengkapan data dan informasi yang sesuai dengan fokus penelitian maka yang dijadikan teknik pengumpulan data dalam penelitian ini menggunakan kuesioner. Penulis simpulkan bahwa dengan menggunakan pola matriks IFAS dan EFAS yang telah dilakukan maka dapat diketahui kondisi Kelurahan Galur dalam melakukan pengembangan terhadap sistem informasi berbasis E-KTP yaitu dengan kemajuan teknologi dan sudah diterapkannya pemberdayaan pegawai dalam bidang teknologi maka dapat meningkatkan lagi visi dan misi yang mendukung kualitas pelayanan Kelurahan.

Kata Kunci - Sistem Informasi, E-KTP, Kelurahan Galur, SWOT.

1,2 Program Vokasi (D3), Institut Ilmu Sosial dan Manajemen STIAMI, Jl. Tipar Cakung No. 81A, Jakarta Timur tlp: 02122476600;e-mail:endangs2013@gmail.com,

mayasofiana72@gmail.com

\section{PENDAHULUAN}

Dalam dunia teknologi informasi saat ini sangatlah berpengaruh terhadap kualitas suatu instansi. Perkembangan teknologi informasi tidak hanya digunakan untuk mengakses informasi saja, akan tetapi digunakan juga dalam menciptakan sebuah sistem yang terintegrasi dengan baik [1] Perkembangan teknologi informasi telah di terapkan juga oleh pihak pemeritahan. Pemerintah Indonesia merencanakan penyelenggaraan pemerintah dengan memanfaatkan teknologi informasi dan komunikasi, dan hal ini di tunjukan pada Peraturan Presiden No. 95 Tahun 2018 tentang Sistem Pemerintahan Berbasis Elektronik (SPBE) [2]. Sistem ini diselenggarakan dengan prinsip keterpaduan, efektifitas, kesinambungan efesiensi, interoperabilitas, akuntabilitas, dan keamanan. Dimana prinsip prinsip yang ada menjadi pedoman bagi pihak yang terlibat dalam penyelenggaraan sistem pemerintahan berbasis elektronik [3].

Seiring dengan perkembangan teknologi informasi dan komunikasi yang semakin pesat saat ini sangatlah memungkinkan masyarakat untuk bisa mengakses informasi apa saja yang mereka butuhkan dalam kehidupan sehari-hari, seolah-olah tidak ada batasannya. Dengan terintegrasinya sistem teknologi dan informasi ini juga berdampak kepada lembaga publik seperti pemerintah daerah. Sistem pemerintahan daerah sekarang ini sudah mulai diintegrasikan dalam suatu teknologi yang dapat dikendalikan dari pusat pemerintahan. Sebagai contoh adalah dengan adanya penerapan electronic-government (e-government) yang mulai diterapkan di Indonesia. Penerapan e-government di Indonesia, dibidani oleh adanya Instruksi Presiden No. 3/2003 tentang Kebijakan dan Strategi Nasional pengembangan e-government. Tidak disangkal lagi bahwa teknologi informasi dan komunikasi dapat digunakan untuk menunjang dalam sistem operasional dan manajerial dari berbagai kegiatan institusi yang di dalamnya termasuk kegiatan pemerintahan dalam hal penyelenggaraan pelayanan publik kepada masyarakat. [4]

Salah satu program yang mulai diterapkan sekarang ini oleh Kementrian Dalam Negeri Republik Indonesia adalah dengan memanfaatkan teknologi informasi dalam melakukan pelayanan kepada masyarakat adalah berupa penerapan program Kartu Tanda Penduduk Elektronik atau disebut juga e-KTP. e-KTP adalah kartu penduduk elektronik yaitu, alat teknologi komunikasi pada era modern ini yang sangat popular di seluruh dunia misalnya di negara-negara di Eropa antara lain Austria, Belgia, Estonia, Italia, Finlandia, Serbia, Spanyol dan Swedia, di Timur Tengah yaitu Arab Saudi, Uni Emirat Arab, Mesir dan Maroko, dan di Asia yaitu China. [4] 
KTP Elektronik adalah dokumen kependudukan yang memuat sistem keamanan / pengendalian baik dari sisi administrasi ataupun teknologi informasi pada data base ke pendudukan nasional [5]. Hal ini sesuai dengan amanat Undang-Undang No. 23 Tahun 2006 tentang Administrasi Kependudukan, dimana pada pasal 101 huruf a, undangundang tersebut dijelaskan bahwa memerintahkan kepada pemerintah untuk memberikan NIK kepada setiap penduduk paling lambat tahun 2011. Selain itu, undang-undang ini juga diperkuat dengan Peraturan Presiden No. 26 Tahun 2009 tentang Penerapan KTP berbasis NIK secara nasional [4]. Penduduk hanya diperbolehkan memiliki 1 (satu) KTP yang tercantum nomor induk kepandudukan (NIK). NIK merupakan identitas tunggal setiap penduduk dan berlaku seumur hidup. Pelayanan Administrasi Kependudukan di Indonesia semakin hari dituntut semakin lebih baik. Program KTP Elektronik pada masyarakat adalah untuk mengganti menggantikan KTP yang lama sebagai bentuk pelayanan kepada masyarakat dengan menyesuaikan tehnologi informatika [5].

Dalam strategi pengembangan sistem informasi berbasi EKTP yang diterapkan oleh kelurahan galur kecamatan johar baru. Terdapat kelebihan dan kekurangan dalam mengembangkan pelayanan dalam pembuatan E-KTP. Maka dari itu strategi peningkatan kualitas layanan kepada masyarakat sangat diperlukan agar dapat mencapai sasaran yang diharapkan. Dengan penggunaan analisis SWOT sehingga dapat menentukan strategi peningkatan kualitas pelayanan dalam pengembangan sistem informasi, dimana analisis ini dilakukan untuk mencari kelebihan, kekurangan, peluang dan ancaman dalam pengembangan sistem informasi berbasis E-KTP di kantor kelurahan Galur.

\section{TINJAUAN PUSTAKA}

\subsection{Sistem Informasi}

Sistem Informasi adalah suatu sistem yang berada dalam suatu organisasi yang mengelola kebutuhan pengolahan transaksi harian yang mendukung operasi dan juga dalam kegiatan strategi dalam suatu organisasi dengan menyediakan laporan-laporan yang diperlukan [6]. Sedangkan menurut Sutabri dalam jurnal [7], Sistem informasi adalah suatu sistem didalam suatu organisasi yang mempertemukan kebutuhan pengolahan transaksi harian yang mendukung fungsi organisasi yang bersifat manajerial dalam kegiatan strategi dari suatu organisasi untuk dapat menyediakan kepada pihak luar tertentu dengan laporan laporan yang diperlukan.

Analisis SWOT

SWOT adalah singakatan dari Strengths (kekuatan), Weaknesses (kelemahan), Opportunities (peluang), dan Threats (ancaman). Analisis SWOT mengatur kekuatan, kelemahan, peluang, dan ancaman utama Anda ke dalam daftar yang terorganisir dan biasanya disajikan dalam bilah kisi-kisi yang sederhana. Strengths (kekuatan) dan Weaknesses (kelemahan) adalah berasal dari internal perusahaan Anda. hal-hal yang dapat Anda kontrol dan dapat berubah. Contohnya termasuk siapa yang ada di tim Anda, paten dan properti intelektual Anda, dan lokasi Anda. Opportunities (peluang) dan Threats (ancaman) adalah hal eksternal yang mempengaruhi bisnis atau hal-hal yang terjadi di luar perusahaan Anda pada pasar yang lebih besar. Anda dapat memanfaatkan peluang dan melindungi dari ancaman, tetapi Anda tidak dapat mengubahnya. Contohnya termasuk pesaing, harga bahan baku, dan tren belanja pelanggan. Teknik ini dibuat oleh Albert Humphrey, yang memimpin proyek riset pada Universitas Stanford pada dasawarsa 1960an dan 1970-an dengan menggunakan data dari perusahaanperusahaan Fortune 500. [8]

Dibawah ini merupakan tabel dalam membentuk Matriks SWOT [9] :

\begin{tabular}{|c|c|c|}
\hline EFAS & $\begin{array}{l}\text { Strength }(\mathrm{S}) \\
\text { Daftar } \\
\text { kekuatan } \\
\text { dimiiliki }\end{array}$ & $\begin{array}{lr}\text { Weakness ( W ) } \\
\text { Daftar } & \text { semua } \\
\text { kelemahan } & \text { yang } \\
\text { dimiliki } & \end{array}$ \\
\hline $\begin{array}{l}\text { Opportunities }(\mathrm{O}) \\
\text { Daftar semua } \\
\text { peluang yang dapat } \\
\text { diindetifikasi }\end{array}$ & $\begin{array}{lr}\text { Strategi SO } & \\
\text { Gunakan } & \text { semua } \\
\text { kekuatan } & \text { yang } \\
\text { dimiliki } & \text { untuk } \\
\text { memanfaatkan } & \\
\text { peluang yang ada }\end{array}$ & $\begin{array}{l}\text { Strategi WO } \\
\text { Atasi semua } \\
\text { kelemahan dengan } \\
\text { memanfaatkan } \\
\text { semua peluang yang } \\
\text { ada }\end{array}$ \\
\hline $\begin{array}{l}\text { Threaths ( } \mathrm{T} \text { ) } \\
\text { Daftar semua } \\
\text { ancaman yang } \\
\text { dapat diidentifikasi }\end{array}$ & $\begin{array}{lr}\text { Strategi ST } & \\
\text { Gunakan } & \text { semua } \\
\text { kekuatan } & \text { untuk } \\
\text { menghindari } & \text { dari } \\
\text { semua ancaman } & \end{array}$ & $\begin{array}{l}\text { Strategi WT } \\
\text { Tekan } \\
\text { kelemahan } \\
\text { cegah } \\
\text { ancaman }\end{array}$ \\
\hline
\end{tabular}

Table 1. Matriks SWOT

Dalam sebuah analisis data yang dilakukan dengan menggunakan analisis SWOT, maka data yang dikumpulkan oleh peneliti yaitu terkait SWOT untuk akhirnya dirumuskan strategi pemasaran yang tepat untuk diterapkan dalam perusahaan [10]. Dibawah ini merupakan gambar diagram SWOT yang akan digunakan dalam menentukan strategi pengembangan perusahaan [11]:

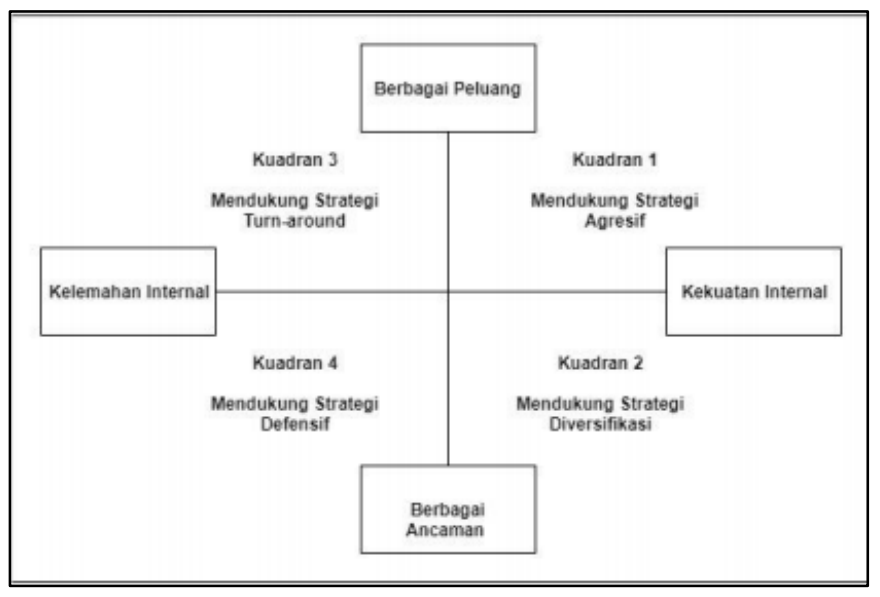

Gambar 1. Diagram SWOT 
Analisis SWOT merupakan analisis yang didasarkan terhadap pemikiran atau rencana akan suatu strategi yang efektif dan efisien dalam memaksimalkan suatu kekuatan dan peluang perusahaan serta meminimalkan kelemahan dan ancaman pada perusahaan. Jika dalam penerapannya telah dilakukan dengan benar maka analisis SWOT ini dapat berdampak sangat besar atas keberhasilan dalam pengembangan perusahaan ataupun organisasi yang mampu menghasilkan informasi yang dibutuhkan untuk identifikasi peluang serta ancaman atau faktor ekternal yang terjadi pada perusahaan [12].

Adapun manfaat dari pengguna analisis SWOT adalah sebagai berikut [13]:

1. Perusahaan akan menjadi lebih memahami kekuatannya dan memberikan rekomendasi untuk meningkatkan perusahaannya.

2. Perusahaan akan dapat melihat suatu peluang dan dapat mempertahankan peluang.

3. Perusahaan mengetahui suatu kelemahan serta mencari solusi untuk mengurangi kelemahan tersebut.

4. Perusahaan mengetahui suatu potensi ancaman serta mencari solusi untuk menghindari ancaman tersebut.

\section{METODE PENELITIAN}

Metode yang digunakan dalam penelitian ini adalah metode deskriptif dan metode survey. Menurut Singarimbun [14] Metode penelitian survey adalah penelitian yang mengambil sampel dari satu populasi dan menggunakan kuesioner sebagai alat pengumpulan data yang pokok. Teknik ini digunakan untuk mengamati secara langsung objek penelitian di lapangan. Menurut Surakhmad dalam [15]: "Penelitian deskriptif tidak terbatas hanya sampai pada pengumpulan dan penyusunan data, tetapi meliputi analisis dan interpretasi data itu sendiri".

\subsection{Pengumpulan Data}

Untuk memperoleh data yang diharapkan dapat menunjang penelitian, penulis melakukan pengumpulan data dengan teknik sebagai berikut:

1. Observasi Lapangan

Teknik observasi lapangan dilakukan untuk mendapatkan data yang aktual dan langsung dengan melakukan pengamatan dan pencatatan secara sistematis terhadap gejala atau fenomena yang ada pada objek penelitian Selain itu observasi lapangan dilakukan untuk mengobservasi lokasi, baik kondisi fisik maupun keadaan masyarakat daerah penelitian dengan terjun langsung ke lapangan Teknik ini digunakan untuk mengamati secara langsung aktivitas masyarakat di lapangan.

2. Angket/Kuesioner

Angket digunakan untuk mengukur persepsi dan sikap masyarakat. Dilakukan dengan mengajukan lembaran angket yang berisi daftar pertanyaan kepada responden.
Daftar pertanyaan tersebut sifatnya tertutup, maksudnya jawaban alternatif telah disediakan kecuali daftar pertanyaan mengenai identitas responden bersifat terbuka.

Angket yang digunakan merupakan tes skala sikap yang mengacu kepada parameter skala Likert. Pilihan jawaban dikategorikan sebagai suatu penyataan sikap SS (sangat setuju), S (setuju), TS (tidak setuju), dan STS (sangat tidak setuju). Kategori ragu-ragu (R) tidak diikutsertakan untuk menghindari sikap keragu-raguan pada masyarakat. Angket ini diberikan setelah keseluruhan tahapan pelaksanaan selesai dilakukan.

3. Wawancara

Teknik ini digunakan utnuk memperoleh data atau informasi langsung dari narasumber mengenai berbagai hal yang berhubungan dengan masalah penelitian. Informasi diperoleh dengan cara bertanya langsung kepada responden, pemuka masyarakat dan aparat desa yang dapat memberikan informasi yang diperlukan. Wawancara dilakukan dengan menggunakan pedoman wawancara, angket atau kuesioner.

Teknik pengumpulan data ini dilakukan dengan terlebih dahulu membuat instrumennya. Pedoman wawancara yang berisi sejumlah pertanyaan yang harus diisi oleh responden ini, merupakan salah satu sumber data utama dalam penelitian ini. Informasi yang didapat berupa keterangan pribadi dan pandangan pribadi dari responden bersangkutan yang berkaitan dengan permasalahan yang dibahas.

4. Studi Dokumentasi

Studi dokumentasi yaitu teknik pengumpulan data dengan melihat berbagai dokumen yang ada di berbagai instansi-instansi atau lembaga-lembaga yang terkait dengan penelitian. Data yang dikumpulkan adalah datadata dari lembaga yang berhubungan dengan penelitian seperti BAPPEDA, Kantor desa untuk mencari data monografi, Kantor satker Jatigede untuk memperoleh data mengenai masyarakat yang tinggal di daerah calon genangan. Studi dokumentasi ini ini digunakan untuk memperoleh data sekunder.

5. Studi Literatur

Studi literatur adalah mempelajari buku-buku yang berkaitan dengan masalah yang dibahas, baik pendapatnya sebagai dasar teori maupun sebagai pembanding dalam pemecahan masalah.

Teknik ini bertujuan untuk mengumpulkan berbagai informasi dari berbagai dokumen-dokumen yang diperlukan dalam penelitian berupa peta tabel tabel makalah, dokumen atau data-data dari instansi pemerintahan.

\subsection{Pengolahan Data}

Pengolahan data adalah suatu proses dalam memperoleh data ringkasan atau angka ringkasan dengan menggunakan cara-cara atau rumus-rumus tertentu. Pengolahan data dalam penelitian ini meliputi: 
a. Editing

Editing adalah pengecekan atau pengkoreksian data yang telah dikumpulkan karena kemungkinan data yang masuk (raw data) atau data yang terkumpul tidak logis dan meragukan Tujuan editing adalah untuk menghilangkan kesalahan-kesalahan yang terdapat pada pencatatan di lapangan dan bersifat koreksi. Pada kesempatan ini, kekurangan data atau kesalahan data dapat dilengkapi atau diperbaiki baik dengan pengumpulan data ulang atau dengan interpolasi (penyisipan).

b. Coding

Coding adalah pemberian/pembuatan kode-kode pada tiap-tiap data yang termasuk dalam kategori yang sama. Kode adalah isyarat yang dibuat dalam bentuk angkaangka/huruf-huruf yang memberikan petunjuk atau identitas pada suatu informasi atau data yang akan dianalisis.

c. Skoring

Proses penentuan skor atas jawaban responden yang dilakukan dengan membuat klasifikasi dan kategori yang cocok tergantung pada anggapan atau opini responden. Penghitungan scoring dilakukan dengan menggunakan Skala Likert yang pengukurannya sebagai berikut [16]:

a) Skor 4 untuk jawaban sangat setuju

b) Skor 3 untuk jawaban setuju

c) Skor 2 untuk jawaban tidak setuju

d) Skor 1 untuk jawaban sangat tidak setuju

d. Tabulasi

Tabulasi adalah membuat tabel-tabel yang berisikan data yang telah diberi kode sesuai dengan analisis yang dibutuhkan.

e. Penyajian data tersusun

Hasil penyusunan dan pengelompokan data di atas, data dapat disajikan dalam bentuk tabel, gambar, bagan dan peta.

\section{HASIL DAN PEMBAHASAN}

\subsection{Analisis SWOT}

Dari hasil pengumpulan data yang telah dilakukan, maka penjabaran analisis SWOT pada kelurahan Galur Jakarta Pusat terlihat pada tabel dibawah ini yaitu penjabaran mengenai faktor kekuatan,kelemahan,peluang serta ancaman yang terdapat pada Kelurahan Galur, dan dibawah ini merupakan faktor-faktor SWOT yang terdapat pada Kelurahan Galur yang telah dianalisis :

\begin{tabular}{|l|}
\hline \multicolumn{1}{|c|}{ Kekuatan (Strenghts) } \\
\hline Sesuai dengan misi yang ada \\
\hline Pengelolaan permohonan perizinan \\
\hline $\begin{array}{l}\text { Kepercayaan masyarakat terhadap } \\
\text { pelayanan kelurahan }\end{array}$ \\
\hline \multicolumn{1}{|c|}{ Peluang (Opportunities) } \\
\hline Dukungan akan perencanaan sistem \\
\hline Penerapan kemajuan internet \\
\hline Pemberdayaan pegawai akan teknologi \\
\hline \multicolumn{2}{|c|}{ Kelemahan(Weaknesses) } \\
\hline Alat untuk perekam tanda tangan \\
\hline Sikap staff yang kurang ramah \\
\hline $\begin{array}{l}\text { Kurangnya pemahaman staff dalam } \\
\text { penggunaan peralatan komputer }\end{array}$ \\
\hline \\
\hline Ancaman(Threats) \\
\hline Serangan virus akan dokumen kantor \\
\hline Kebocoran data \\
\hline Jaringan internet yang tidak stabil \\
\hline
\end{tabular}

Table 2. Hasil Analisis SWOT

\subsection{Internal Strategic Factory Analysis Summary (IFAS) dan} Eksternal Strategic Factory Analysis Summary (EFAS)

Dari hasil pengamatan yang dilakukan pada kasus Kelurahan Galur kota Jakarta Pusat dapat ditarik kesimpulan berbagai strategi yang dapat di tawarkan dalam mengembangkan sistem informasi berbasis E-KTP untuk mendukung visi dan misi kelurahan. Hal tersebut dapat digambarkan dalam bentuk matrik analisis SWOT, seperti yang dapat digambarkan sesuai dengan analisis strategi factor internal dan analisis strategi factor ekternal.

Seperti yang terlihat pada gambar berikut ini yang ditampilkan dalam bentuk table matrik analisis SWOT. 


\begin{tabular}{|c|c|c|}
\hline IFAS & KEKUATAN (S) & $\begin{array}{l}\text { KELEMAHA } \\
\mathbf{N}(\mathbf{W})\end{array}$ \\
\hline EFAS & $\begin{array}{l}\text { 1. Sesuai dengan } \\
\text { misi yang ada } \\
\text { 2. Pengelolaan } \\
\text { permohonan } \\
\text { perizinan } \\
\text { 3. Kepercayaan } \\
\text { masyarakat } \\
\text { terhadap layanan } \\
\text { pemerintahan }\end{array}$ & $\begin{array}{l}\text { 1. Alat untuk } \\
\text { perekam } \\
\text { tanda } \\
\text { tangan } \\
\text { 2. Sikap staff } \\
\text { yang kurang } \\
\text { ramah } \\
\text { 3. Kurangnya } \\
\text { pemahaman } \\
\text { staff dalam } \\
\text { penggunaan } \\
\text { peralatan } \\
\text { komputer }\end{array}$ \\
\hline $\begin{array}{l}\text { PELUANG } \\
\text { (O) }\end{array}$ & STRATEGI SO & $\begin{array}{c}\text { STRATEGI } \\
\text { WO }\end{array}$ \\
\hline $\begin{array}{l}\text { 1. Dukungan } \\
\text { akan } \\
\text { perencana } \\
\text { an sistem } \\
\text { 2. Penerapan } \\
\text { kemajuan } \\
\text { internet } \\
\text { 3. Pemberda } \\
\text { yaan } \\
\text { pegawai } \\
\text { akan } \\
\text { teknologi } \\
\text { 4. Penerapan } \\
\text { Perpres RI } \\
\text { No } 95 \\
\text { tahun } \\
\text { 2018 }\end{array}$ & $\begin{array}{l}\text { 1. Dengan kemajuan } \\
\text { teknologi dan } \\
\text { sudah dah dapat } \\
\text { diterapkannya } \\
\text { pemberdayaan } \\
\text { pegawai dalam } \\
\text { bidang teknologi } \\
\text { maka dagi } \\
\text { meningkatkan lagi } \\
\text { visi dan misi yang } \\
\text { mendukung } \\
\text { kualitas pelayanan } \\
\text { Kelurahan. } \\
\text { 2. Dengan adanya } \\
\text { Perpres RI NO } 95 \\
\text { Tahun } 2018 \\
\text { mengenai sistem } \\
\text { pemerintahan } \\
\text { berbasis } \\
\text { elektronik maka } \\
\text { dengan ini dapat } \\
\text { lebih } \\
\text { meningkatkan } \\
\text { pengelolaan } \\
\text { permohonan akan } \\
\text { perizinan }\end{array}$ & $\begin{array}{l}\text { 1. Sistem yang } \\
\text { digunakan } \\
\text { akan lebih } \\
\text { baik jika } \\
\text { menggunaka } \\
\mathrm{n} \text { sistem } \\
\text { teknologi } \\
\text { yang teri } \\
\text { 2. ntegrasi } \\
\text { sehingga } \\
\text { dapat sat } \\
\text { membantu } \\
\text { dalam sisi } \\
\text { pelayanan } \\
\text { masyarakat } \\
\text { agar tidak } \\
\text { lagi lemah }\end{array}$ \\
\hline $\begin{array}{l}\text { ANCAMAN } \\
\text { (T) }\end{array}$ & STRATEGI ST & $\begin{array}{c}\text { STRATEGI } \\
\text { WT }\end{array}$ \\
\hline $\begin{array}{ll}\text { 1. } & \begin{array}{l}\text { Serangan } \\
\text { virus } \\
\text { akan } \\
\text { dokumen } \\
\text { kantor }\end{array} \\
\text { 2. } & \begin{array}{l}\text { Kebocor } \\
\text { an data }\end{array} \\
\text { 3. } & \text { Jaringan } \\
\text { internet } \\
\text { yang } \\
\text { tidak } \\
\text { stabil }\end{array}$ & $\begin{array}{l}\text { 1. Dengan } \\
\text { menggunakan } \\
\text { sistem kendali } \\
\text { layanan publik, } \\
\text { sistem yang ada } \\
\text { digunakan pada } \\
\text { komputer dan } \\
\text { mengurangi } \\
\text { tingkat penipuan } \\
\text { dokumen yang } \\
\text { ada. }\end{array}$ & $\begin{array}{l}\text { 1. Peningkatan } \\
\text { teknologi } \\
\text { yang baik } \\
\text { dan } \\
\text { terintegrasi } \\
\text { dapat } \\
\text { melakukan } \\
\text { penyebaran } \\
\text { informasi } \\
\text { yang baik. } \\
\text { 2. Keamanan } \\
\text { yang lebih } \\
\text { ditingkatkan } \\
\text { sehingga } \\
\text { dapat } \\
\text { menghindari } \\
\text { pembocoran } \\
\text { dokumen }\end{array}$ \\
\hline
\end{tabular}

\section{KESIMPULAN DAN SARAN}

\subsection{Kesimpulan}

Berdasarkan analisis SWOT yang telah dilakukan, maka dapat dirumuskanlah kesimpulan atas analisis strategi yang didapat. Dengan menggunakan pola perhitungan nilai IFAS dan EFAS yang telah dilakukan maka dapat di ketahui posisi atau kondisi kelurahan Galur pada saat ini. Sehingga nilai yang dihasilkan dari perhitungan ini dapat digunakan dalam peningkatan strategi pelayanan kelurahan dengan mengembangkan sistem informasi sesuai dengan kondisi perusahaan secara tepat.

1. Dengan adanya tuntutan implementasi good governance (tata pemerintahan yang baik) dan peningkatan pelayanan publik, maka analisis SWOT ini dirasa sangat tepat dalam awal mula menentukan strategi perkembangan perusahaan ataupun organisasi. Sehingga kelurahan Galur dapat menentukan strategi yang tepat dalam meningkatkan kualias organisasinya dengan memperhatikan faktor internal dan faktor eksternal yang telah diketahui.

2. Potensi kekuatan serta peluang yang ada pada kelurahan Galur kecamatan Johar Baru ini sangatlah tinggi, hal ini berpengaruh baik dalam hal peningkatan kualitas layanan kepada masyarakat. Serta hal ini menjadi proses yang baik bagi kelurahan dalam peningkatan kualitas organisasi.

3. Dalam perhitungan IFAS serta EFAS yang telah dilakukan, maka dapat diketahui dalam diagram analisis SWOT bahwa kelurahan Galur kecamatan Johar Baru terdapat pada kuadran I yang artinya kondisi kelurahan Galur ada dalam posisi mendukung strategi agresif. Dengan pemanfaatan peluang yang telah terbentuk sehingga dapat memaksimalkan segala kekuatan yang ada pada kelurahan Galur. Pemanfaatan ini dirasa sangat dibutuhkan terutama dalam memaksimal potensi internal di wilayah kantor kelurahan. Peningkatan dalam hal pelayanan kepada masyarakat dapat lebih ditingkatkan lagi secara maksimal dengan pemanfaatan peluang yang ada. Dan hal ini menjadi kesempatan yang baik bagi kelurahan Galur dalam peningkatan potensi baik secara internal maupun eksternal.

5.2. Saran

Pengembangan teknologi informasi atau sistem informasi sangat dibutuhkan oleh kantor kelurahan Galur demi memenuhi kebutuhan data serta informasi yang baik, valid dan terintegrasi. Pembuatan sistem informasi mengenai pelayanan terhadap masyarakat dirasa cukup efektif dilakukan agar sistem yang ada dapat lebih dikembangkan lagi dan dapat memaksimalkan peluang yang ada baik terhadap sarana maupun prasarana yang ada di wilayah kantor kelurahan Galur dengan sangat baik dan dapat mengoptimalkan sistem kerja secara maksimal. Untuk para staff agar meningkatkan kemampuannya dalam menggunakan komputer dan meningkatkan sikap ramah terhadap masyarakat. 


\section{UCAPAN TERIMA KASIH}

Ucapan terima kasih kami sampaikan kepada semua pihak yang telah membantu penyelesaian karya ilmiah khususnya semua staff kelurahan Galur Jakarta Pusat yang telah banyak memberikan informasi yang dibutuhkan oleh kami. Dan tidak

\section{REFERENSI}

[1] M. S. Putra, "Faktor-Faktor Pengembangan Sistem Informasi Akademik Berbasis Web Pada Perguruan Tinggi Swasta Palembang," J. RESTI (Rekayasa Sist. dan Teknol. Informasi), pp. 295-300, 2018.

[2] P. P. R. N. 9. T, "Peraturan Presiden Republik Indonesia No 95 Tahun 2018 Tentang Sistem Pemerintahan Berbasis Elektronik,” p. 199, 2018.

[3] I. D. a. R. M. M. Z. Syafnel, "Analisis dan Perancangan TataKelola Data sistem Pemerintahan Berbasis Elektronik Domain Master Data Management (MDM) pada Dama Dmbok V2 di Diskominfotik Kbb," p. 7775-7786, 2019.

[4] T. R. V. RONI EKHA PUTERA, "Implementasi Program KTP Elektronik (e-KTP) di Daerah Percontohan," MIMBAR, pp. 193-201, 2011.

[5] M. P. Febriharini, "Pelaksanaan Program e KTP Dalam Rangka Tertib Administrasi Kependudukan," Jurnal Ilmiah UNTAG Semarang, pp 2302-2752, 2016.

[6] I. Irawan, "Pengembangan Sistem Informasi Akademik Universitas Pahlawan Tuanku Tambusai Riau," J. Teknol. Dan Open Source, pp. 55-66, 2018.

[7] S. a. D. S. Paryanta, "Sistem Informasi Administrasi Kependudukan Berbasis Web Desa Sawahan," IJSE - Indones. J. Softw. Eng, pp. 1-8, 2017.

[8] N. W. UTAMI, “Jurnal Enterpreneur,” 26 February 2019. [Online]. Available: https://www.jurnal.id/id/blog/2017-manfaat-faktor-yangmemengaruhi-dan-contoh-analisis-swot/. [Accessed 2210 2020].

[9] M. A. a. R. Sanjaya, "Strategi Perencanaan dan Pengembangan Program Studi Menggunakan Analisis SWOT (Studi Kasus Program Studi Sistem Informasi ARS University),” pp. 1-8, 2020.

[10] O. A. B. D. H. S. a. L. P. P. R. Veriyadna, "Penerapan Analisis SWOT: Studi Kasus Usaha Mahasiswa Creative Puzzle Glass,” pp. 1-6, 2019.

[11] A. W. a. Suyudi, "Penerapan Analisis SWOT Dalam Menentukan Strategi Pengembangan Sistem Informasi STIKOM Yos Sudarso Purwokerto," J. Chem. Inf.Model., pp. 1689-1699, 2018.

[12] S. Noor, "Penerapan Analisis Swot dalam Menentukan Strategi Pemasaran Daihatsu Luxio di Malang," J. INTEKNA, p. 102-209, 2014.

[13] G. Pendidikan, "Analisis SWOT : Pengertian, Unsur, Manfaat, Faktor, Contoh, Kelebihan \& Kekurangannya Lengkap,” seputarilmu.com, 2019.

[14] S. E. Masri Singarimbun, Metode Penelitian Survai, Jakarta: Pusa LP3ES Indonesia, 1987.

[15] W. Surakhmad, Pengantar Penelitian Ilmiah Dasar Metode Teknik, Bandung: Tarsito, 1994.

[16] Riduwan, Skala Pengukuran Variabel-Variabel Penelitian, Bandung: Alfabeta, 2009 lupa juga kami ucapkan terima kasih kepada staff pengurus jurnal sistem informasi STMIK Antar Bangsa yang memperkenankan artikel kami dipublish pada journal JSI STMIK Antar Bangsa.

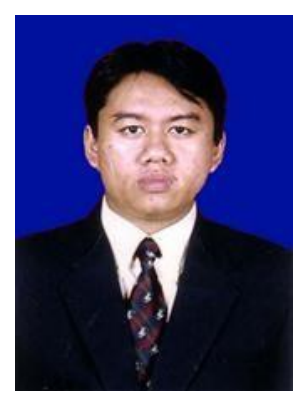

Endang Supriyadi, lahir di Jakarta, 14 Nopember 1974. Memperoleh gelar Diploma III (D3), Jurusan Manajemen Informatika Universitas Gunadarma Depok, lulus tahun 1998 dan memperoleh gelar Sarjana Al-Quran (SQ) dan gelar Sarjana Agama (S.Ag) Fakultas Tarbiyah Jurusan Pendidikan Agama Islam di Institut Perguruan Tinggi Ilmu Al-qur'an Jakarta ( IPTIQ ) lulus tahun 1999. Memperoleh gelar Magister Komputer (M.Kom) Program Pasca Sarjana Magister Ilmu Komputer Konsentrasi E-Business STMIK Nusa Mandiri Jakarta, lulus tahun 2015. Pernah mengajar di STMIK Nusa Mandiri Jakarta, STIMA IMMI, STMIK Triguna Utama dan saat ini aktif mengajar di beberapa perguruan tinggi swasta lainnya : Politeknik LP3I Jakarta Kampus Depok, Institut Ilmu Sosial dan Manajemen STIAMI, Insititut Bisnis dan Ilmu Komputer ( IBIK57 ) Kosgoro serta menjadi anggota tim asesor LSP Politeknik LP3I Jakarta untuk kompetensi bidang ilmu komputer. Pendiri lembaga kursus komputerLKP-PROTECH Depok ( WWW.LKPPROTECH.COM ) dan pendiri cadastrmnet wilayah pancoranmas Depok. Selain itu aktif pula menulis buku panduan komputer aplikasi perkantoran dan artikel ilmiah yang pernah di publish dintaranya : Metode SVM Berbasis PSO untuk Meningkatkan Prediksi Ketepatan Waktu Kelulusan Mahasiswa, Analisa Web untuk Memahami Perilaku Konsumen Online Studi Kasus "Store Steam Powered" dll.

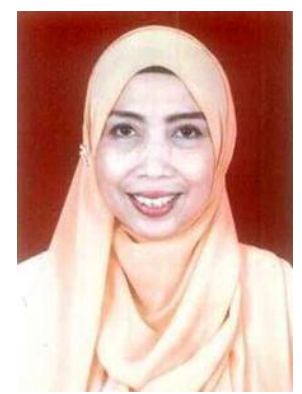

Maya Sofiana, lahir di Surabaya, 13 Mei 1972. Memulai pendidikan di Sekolah Menengah Atas Negeri (SMAN) 52, Jakarta lulus tahun 1991. Kemudian melanjutkan ke Ikip Jakarta $\mathrm{d} / \mathrm{h}$ Universitas Negeri Fatultas Ilmu sosialProgram Studi Administrasi Perkantoran Jakarta tahun 1992 dan lulus tahun 1997. Lalu tahun 1998 melanjutkan Strata Dua (S2) Magister Manajemen di Universitas Jayabaya Jakarta lulus tahun 2000. Pernah bekerja di PT Aditya Apprasial Bhakti tahun 2000. Kemudian Tahun 2003. bekerja di Yayasan Widya Bhakti. Saat ini mengajar di beberapa kampus swasta Institut Ilmu Sosial dan Manajemen Stiami, Poltek LP3I Jakarta dan memberikan pelatihan Perkantoran karyawan di beberapa instansi Kemendikbud, dan Kementerian Pertahanan RI. Paper jurnal yang pernah dipublikasikana adalah sebagai berikut: Pelaksanaan Manajemen K3 pada PT Adyawinsa T 7 E di Jakarta (Majalah Ilmiah Bijak), Pelatihan Pengenalan Aplikasi Perkantoran ( Typing Master dan Word) bagi Remaja Karang Taruna RT 4 Kelurahan Cinere Kecamatan Cinere Depok Jawa Barat (Jurnal Komunitas-Jurnal Pengabdian Kepada Masyarakat), Prosedur Production Control pada PT Astra Honda Motor Jakarta (Jurnal Abiwara-Jurnal Vokasi Administrasi Bisnis), Studi Komparasi Kepuasan Pasien BPJS dan Non BPJS pada Mutu Pelayanan Pendaftaran Puskesma Johar Baru Jakarta Pusat (Jurnal Abiwara-Jurnal Vokasi Administrasi Bisnis), Green Office Concept Assesment in The Council Show The Office Care (Majalah Ilmiah Bijak). 